\title{
Morus alba- A Potential Sorbent for the Removal of Arsenic: Equilibrium, Kinetic and Thermodynamic Study
}

\author{
Mazhar I. Khaskheli ${ }^{*}$, Zaheer Ahmed Chandio ${ }^{2}$, Faiz M. Khokhar ${ }^{3}$, \\ Wahid B. Jatoi ${ }^{4}$, Abdul G. Memon ${ }^{3}$, K. Shaista ${ }^{5}$, \\ Laeeq A. K. Khokhar ${ }^{3}$ and Abdul M. Channa ${ }^{3}$ \\ ${ }^{1}$ Government College University Hyderabad, Pakistan. \\ ${ }^{2}$ Department of Chemistry, Shaheed Benazir Bhutto University, Shaheed Benazirabad Pakistan. \\ ${ }^{3}$ Institute of Advanced Research Studies in Chemical Sciences, University of Sindh, Jamshoro, Pakistan. \\ ${ }^{4}$ Institute of Chemistry, Shah Abdul Latif University, Khairpur Mir's, Pakistan. \\ ${ }^{5}$ Molecular Biology (Genetics) Laboratory, Medical Research Centre, LUMHS, Jamshoro, Pakistan. \\ *Coressponding Author Email: kumailmazhar@gmail.com \\ Received 23 December 2019, Revised 01 June 2020, Accepted 15 June 2020
}

\begin{abstract}
In present study, arsenic (As) uptake potential of an eco-friendly Morus alba (mulberry) leave biomass was analyzed. Surface properties of the sorbent and its affinities for arsenic ions with respect to temperature were studied. Freundlich, D-R, Florry-Huggins and Halsey isotherms were found to be similar with recorded experimental data. Maximum sorption capacities $2.82 \mathrm{mg} / \mathrm{g}$ and $4.93 \mathrm{mg} / \mathrm{g}$ were calculated for $\mathrm{As}(\mathrm{III})$ and $\mathrm{As}(\mathrm{V})$ at $\mathrm{pH}-6$ and $\mathrm{pH}-4$, respectively. The energy values of the sorption 3.31-5.89 $(<8) \mathrm{kJ} / \mathrm{mole}$ indicated the physisorption. The applicability of Halsey isotherm supported the heteroporosity of the biomass. Mechanism of the reaction was best explained by pseudo first order rate, Morris-Weber and Richenberg equations. Intra-particle diffusion as well as surface sorption was noticed during the study. Equilibrium was achieved up to 120 minutes. Thermodynamically, sorption reaction was endothermic and spontaneous in nature. Maximum recoveries of $\mathrm{As}(\mathrm{III})$ and $\mathrm{As}(\mathrm{V})$ were $83.3 \%$ and $95.52 \%$, respectively observed with 1 $\mathrm{M} \mathrm{H}_{2} \mathrm{SO}_{4}$.
\end{abstract}

Keywords: Morus alba, Arsenic, Sorption, Isotherm

\section{Introduction}

For centuries, arsenic (As) has been considered as contaminant [1]. It is non-biodegradable and detrimental to the flora and fauna. As contamination of drinking water can be found in earth's outer layer, marine and ground water. More than 300 species of As bearing minerals exist in nature [2]. As is mobilized through biological activities, volcanic emissions, weathering reactions, anthropogenic activities such as gold mining, copper smelting, petroleum refining, arsenical pigments, combustion of fossil fuels in power plants, arsenical pesticides and herbicides [3].
In 1999, WHO ranked As contamination as "major public health issue". USEPA (1997) and IARC (2004) classified As category 1 (group A) carcinogen [4]. It has mutagenic and tetratogenic capacity to human health (ASTDR 1990). From the various oxidation states $(-3,0,+3,+5), \mathrm{As}$ (III) and $\mathrm{As}(\mathrm{V})$ are widespread in water [5]. Water contains both organic and inorganic As species. Organic arsenicals have much lower toxicities than inorganic As compounds [6]. Inorganic compounds of $\mathrm{As}(\mathrm{V})$ are dominant and stable in oxygen rich surface water environment while $\mathrm{As}(\mathrm{III})$ are in reasonable anaerobic ground water [7]. $\mathrm{As}(\mathrm{III})$ is more mobile and more toxic (25-60 
times) than $\mathrm{As}(\mathrm{V})$ and many times more toxic as compared to organic As species [8]. As(III) is quite difficult to remove as contrast to $\mathrm{As}(\mathrm{V})$, which also exists mostly as deprotonated oxyanions $\left(\mathrm{HAsO}_{4}{ }^{2-}\right)$. As disturbs the regular metabolic activity of living organisms. In mammals its toxicity is due to reaction with sulfhydryl groups of enzymes [9]. Bioaccumulation of As in food chain even in relatively low concentration (greater than $10 \mathrm{ppb}$ ) threatens to human, animal and plant life [10]. As poisoning causes heart disease, anemia, keratosis, hyper pigmentation, gangrene of toes, solid swelling of legs, burning sensation of eyes, neuropathy, liver fibrosis and cancer in lungs, skin, kidney, liver, prostate and bladder [11]. Severe As poisoning causes human even to death.

Keeping in view this potential threat, scientists have employed various techniques for the removal of As from aqueous solution, such as chemical precipitation, solvent extraction, chelating and ion exchange, adsorption, membrane separation and electrochemical methods. However, most of these methods could not be used in fullscale applications due to their high operational cost or potential secondary pollution [12]. It has been observed that in last two decades adsorption technique has received lot of consideration due to the availability of variety of adsorbents. Adsorption is a very economical, simple, effective, highly versatile process for removing harmful pollutants from wastewater [13]. Morus alba leave biomass is locally available and cost effective. It cannot contaminate drinking water during the sorption process. This plant can easily grow in most areas of Pakistan. Further, this plant also bears sweet fruit as well. In comparison to other metal removal techniques, adsorption has numerous advantages such as short operational time, enhanced selectivity for specific metal ions of interest, reusability of biomass, high metal binding efficiency, no production of secondary toxic compounds etc [14]. Methods other than adsorption are not appropriate for small level industries.

The objective of the present work is to investigate the sorption potentials of Morus alba for the removal of $\mathrm{As}(\mathrm{III})$ and $\mathrm{As}(\mathrm{V})$ from real sample solutions. Further, the applicability of the developed method was also analyzed with As contaminated real samples.

\section{Materials and Methods Chemicals}

In the present experimental work all reagents used were of analytical grade. Stock solutions $(1000 \mathrm{mg} / \mathrm{L})$ of $\mathrm{As}(\mathrm{III})$ and $\mathrm{As}(\mathrm{V})$ were prepared by dissolving calculated amounts of arsenic oxide arsenous $\left(\mathrm{As}_{2} \mathrm{O}_{3}\right)$ (Poole, England) and sodium arsenate $\left(\mathrm{Na}_{3} \mathrm{AsO}_{4}\right)$ (Merck, Germany) in de-ionized water respectively. Required working solutions for experiment were freshly prepared from the stock solutions. $\mathrm{pH}$ of solutions were maintained by the various buffers (acetic acid, sodium acetate, potassium chloride, hydrochloric acid and sodium hydroxide). The mixture of $0.2 \%$ w/v sodium borohydride $\left(\mathrm{NaBH}_{4}\right)$ (Darmstadt company, Merck, Germany) in $0.05 \%$ w/v sodium hydroxide $(\mathrm{NaOH})$ (Fisher scientific UK) was used for the reduction of As.

\section{Instrumentation}

pH meter (Thermo Scientific Orion 5 Star, 8102BNUWP; USA), Shaking Incubator 1-40000 Irmeco GmbH (Germany), Atomic Absorption Spectrometer Analyst 800 (Perkin Elmer, Singapore) connected with Flow Injection System for hydride generation (FIAS 100 Perkin Elmer, Singapore) equipped with a hallow cathode lamp having current $18 \mathrm{~mA}$, wavelength $193.7 \mathrm{~nm}$, energy 40, bandwidth $0.7 \mathrm{~nm}$ and Quartz Tube Atomizer (Universal QAT, part number B3000350, Singapore) were used during the sorption experiments.

\section{Sample preparation}

The green Morus alba leaves were collected from the fruit farm of Shoukat Ali Khaskheli, Hussainabad, Kotdiji district Khairpur Mir's, Sindh, Pakistan. Sample leaves were washed many times with water and then with deionized water in order to remove dust and extraneous. Thereafter, leaves were dried in an oven at $60{ }^{\circ} \mathrm{C}$ for one day. The dried biomass was subsequently grounded and sieved into uniform particle size $(0.125-0.42 \mathrm{~mm})$ for the sorption experiments. 


\section{General method}

$10 \mathrm{~mL}$ of test solution was taken in 100 $\mathrm{mL}$ stoppered conical flask. Suitable amount of sorbent was added and then agitated for the stipulated contact time at $200 \mathrm{rpm}$. The experiments were performed at 20,30 and $40{ }^{\circ} \mathrm{C}$. The equilibrium time was estimated by drawing the samples from shaker at regular intervals. The samples were filtered out using filter paper and filtrate was analyzed by using FAAS connected to FIAS system. The stated experimental procedure was repeated for the optimization of different parameters- biomass dosage $(0.05-0.3 \mathrm{~g})$, contact time (0-1440 $\mathrm{min})$, metal concentration (0.01-50 $\mathrm{mg} / \mathrm{L})$ and $\mathrm{pH}(1-10)$.

\section{Results and Discussion FT-IR characterization of Morus alba sorbent}

The FT-IR spectroscopy is a power tool for the direct investigation of the sorption mechanism before and after the loading of metal ions on surface of sorbent. Spectra of sorbent were recorded in range of $500-4000 \mathrm{~cm}^{-1}$ and are presented in Fig. 1. The band ranged from 3280 $3334 \mathrm{~cm}^{-1}$ represented $\mathrm{O}-\mathrm{H}$ (hydrogen bonding) stretching vibration of alcohols or phenols.

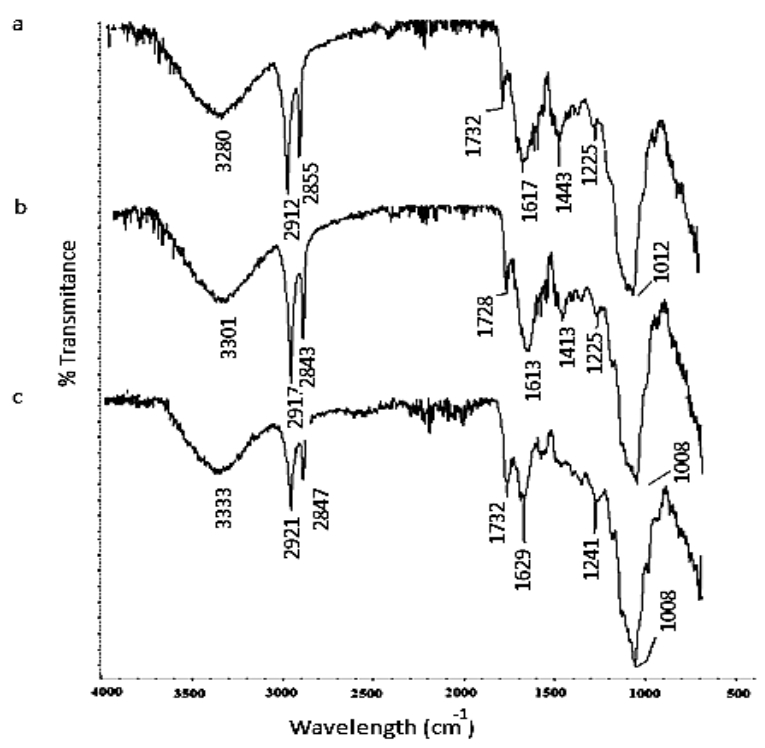

Figure 1. (a) FT-IR specta of Morus alba leaves, (b) Morus alba leaves loaded with As(III) and (c) Morus alba leaves loaded with As(V)
The peaks from $2843-2922 \mathrm{~cm}^{-1}$ and $1723-1728 \mathrm{~cm}^{-1}$ were assigned to the stretching vibrations of $\mathrm{C}-\mathrm{H}$ (alkane) and $-\mathrm{C}=\mathrm{O}$ (carboxylic group). Peaks at $1613-1629 \mathrm{~cm}^{-1}$ and $1413 \mathrm{~cm}^{-1}$ are attributed to bending vibrations of $\mathrm{C}=\mathrm{C}$ (aromatic) and -O-H (carboxylic acid) groups, respectively. The bands at $1008-1012 \mathrm{~cm}^{-1}$ were assigned to the $\mathrm{C}-\mathrm{O}$ stretching of alcohols.

The stretching vibrations at $1413 \mathrm{~cm}^{-1}$ and $2921 \mathrm{~cm}^{-1}$ remained same for As(III) and As(V) loaded sorbent, respectively. The peaks of $\mathrm{O}-\mathrm{H}$ (phenol or alcohol) at $3280.82 \mathrm{~cm}^{-1}$ and $\mathrm{C}-\mathrm{H}$ (aldehyde) $2855.85 \mathrm{~cm}^{-1}$ were shifted for As(III)loaded sorbent and As(V)-loaded Morus alba leaves peak at $1413 \mathrm{~cm}^{-1}$ (-O-H of carboxylic acid) was disappeared in the $\mathrm{As}(\mathrm{V})$ loaded sorbent. The shifts of peaks at $1617 \mathrm{~cm}^{-1}$ and $1012 \mathrm{~cm}^{-1}$ were also observed for $\mathrm{As}(\mathrm{III})$ and $\mathrm{As}(\mathrm{V})$ loaded sorbent. Results demonstrate that the carboxyl ($\mathrm{COOH}), \mathrm{C}=\mathrm{C}$ (aromatic) and $\mathrm{O}-\mathrm{H}$ (alcohol or phenol) groups mainly participate in the sorption of $\mathrm{As}(\mathrm{III})$ and $\mathrm{As}(\mathrm{V})$ onto Morus alba sorbent. The sorption process may be attributed to the ion exchange, physical adsorption, complexation, chemical reaction with surface sites and surface precipitations.

\section{Effect of $p H$}

The $\mathrm{pH}$ plays one of the important role in the sorption of As ions on the Morus alba biomass. The $\mathrm{pH}$ effect on the removal of As(III) and $\mathrm{As}(\mathrm{V})$ on sorbent (Morus alba leaves) was studied in the $\mathrm{pH}$ 1-10 range, results are presented in Fig. 2. In case of As(III) in the range of $\mathrm{pH} 1-5$ and 7-10 sorption is nearly constant. Maximum sorption of $\mathrm{As}(\mathrm{III})$ and $\mathrm{As}(\mathrm{V})$ were $49.3 \%$ and $78 \%$ observed at pH-6 and 4 respectively. Therefore, further studies were carried out at $\mathrm{pH}-6$ for $\mathrm{As}(\mathrm{III})$ and $\mathrm{pH}-4 \mathrm{As}(\mathrm{V})$ respectively. Same trend of $\mathrm{pH}$ with $\mathrm{As}(\mathrm{III})$ and $\mathrm{As}(\mathrm{V})$ was observed in literature [15].

In the above mentioned range of $\mathrm{pH}$, the predominant mono-anionic $\left(\mathrm{H}_{2} \mathrm{AsO}_{3}^{-}\right)$is considered to be responsible for the sorption of As(III), substituting water molecules or hydroxyl ions. $\mathrm{H}_{3} \mathrm{AsO}_{4}, \mathrm{H}_{2} \mathrm{AsO}_{4}{ }^{-}, \mathrm{HAsO}_{4}{ }^{2-}$ and $\mathrm{AsO}_{4}{ }^{3-}$ are the dominant $\mathrm{As}(\mathrm{V})$ species in $\mathrm{pH}$ ranges of $<2.26$, 2.26-6.76, 6.76-11.29 and >11.29, respectively. 
According to Fig. 2 in alkaline $\mathrm{pH}$ both species of As showed decrease in sorption. This can be recognized as the repulsive forces produced between the negatively charge sorbent and anionic species of As [16].

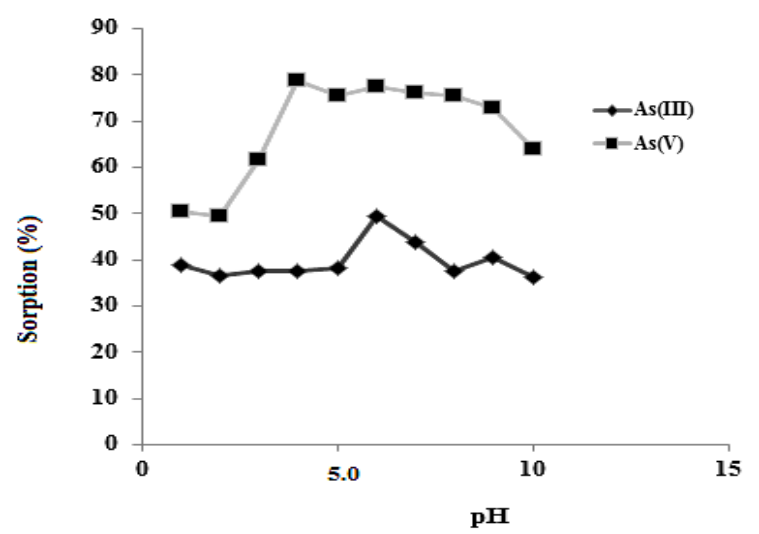

Figure 2. Effect of $\mathrm{pH}$ on removal of $\mathrm{As}(\mathrm{III})$ and $\mathrm{As}(\mathrm{V})$ through Morus alba leaves

\section{Effect of biomass concentration}

Sorption efficiency in terms of amount of biomass was investigated $0.05-0.30 \mathrm{~g}$ with an interval of $0.05 \mathrm{~g}$ by maintaining all the other parameters at their optimal values such as metal ion concentration $5 \mathrm{mg} / \mathrm{L}$, volume $10 \mathrm{~mL}$, temperature $30{ }^{\circ} \mathrm{C}$, agitation time $30 \mathrm{~min}$, shaking speed $250 \mathrm{rpm}, \mathrm{pH}-6$ for $\mathrm{As}(\mathrm{III})$ and $\mathrm{pH}-4 \mathrm{As}(\mathrm{V})$. Generally, it has been observed that there was slight increase in sorption as amount of biomass was increased. The increase in sorption can be caused due to the surface area and creation of electrostatic force of attraction between metal and functional group present in Morus alba biomass.

\section{Effect of contact time}

In batch experiments, time play very important role for the optimization of rate of sorption. Therefore, the effect of contact time was studied in the range between $0-1440 \mathrm{~min}$ at $\mathrm{pH}-6$ for $\mathrm{As}(\mathrm{III})$ and $\mathrm{pH}-4$ for $\mathrm{As}(\mathrm{V})$. Results from the Fig. 3 showed that equilibrium was achieved after $120 \mathrm{~min}$. Similar trend of equilibrium time was also seemed for the removal of $\mathrm{As}(\mathrm{V})$ on modified sawdust of spruce [17]. Then decrease in sorption was observed. This decrease may be due to autodesorption of metal ions.

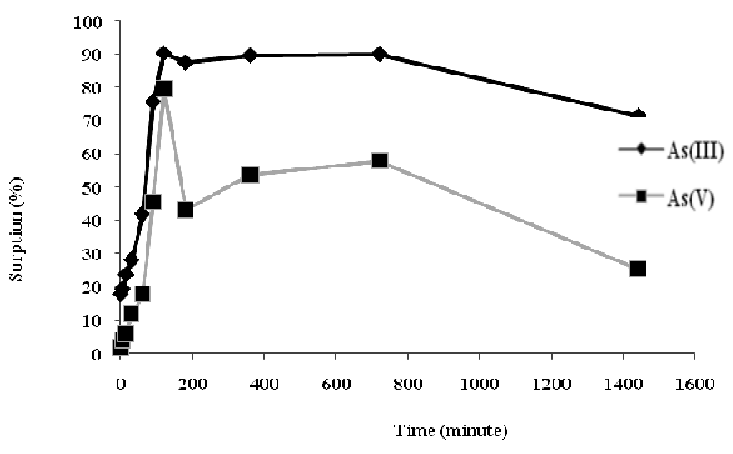

Figure 3. Uptake of As(III) and As(V) on Morus alba leaves as a function of time

\section{Sorption isotherm study}

Isotherm study deals sorbent surface properties and its affinities for ions at fixed temperature and pressure. Experimental sorption data was also applied to the following adsorption isotherm models.

\section{Freundlich adsorption isotherm model}

Like other isotherm models, Freundlich Model is also widely used for the adsorption of variety of organic and in-organic compounds on the surface of various adsorbents (natural and synthetic). The experimental data was applied to the following linear form of the equation 1 .

$\log \mathrm{q}_{\mathrm{e}}=\log \mathrm{K}_{\mathrm{F}}+\frac{1}{\mathrm{n}} \log \mathrm{C}_{\mathrm{e}}$

Where $\mathrm{q}_{\mathrm{e}}$ is amount of metal adsorbed per unit mass of adsorbent, while $\mathrm{C}_{e}$ is amount of metal in the liquid phase at equilibrium, $\mathrm{K}_{\mathrm{F}}$ (Freundlich Constant) relative adsorption capacity and $\mathrm{n}$ is adsorption intensity. $1 / \mathrm{n}<1$ suggest presence of convex isotherm while $1 / \mathrm{n}>1$ concave isotherm [18]. Fit of the experimental data indicates that multilayer of the metal ions are formed on heterogeneous surface (non-equivalent binding sites) of sorbent. The values of $n$ and $K_{f}$ are calculated from intercept and slope respectively from the plot $\log \mathrm{q}_{\mathrm{e}}$ versus $\log \mathrm{C}_{\mathrm{e}}$. Here the calculated values of $\mathrm{n}$ are greater than 1 $(1 / \mathrm{n}<1)$ support the convex isotherm and favorable nature of sorption. Table 1 shows that as temperature increases, $\mathrm{K}_{\mathrm{F}}$ and $\mathrm{n}$ values decreases and vice versa. 
Table 1. Regression parameters for the Fruendlich, D-R adsorption, Florry-Huggins and Halsey isotherms by using Morus alba leaves as sorbent at different temperatures.

\begin{tabular}{|c|c|c|c|c|c|c|}
\hline \multirow{2}{*}{$\begin{array}{c}\text { Metals } \\
\text { Temperature }\left({ }^{\circ} \mathrm{C}\right)\end{array}$} & \multicolumn{3}{|c|}{$\operatorname{As}($ III) } & \multicolumn{3}{|c|}{$\operatorname{As}(\mathbf{V})$} \\
\hline & 20 & 30 & 40 & 20 & 30 & 40 \\
\hline \multicolumn{7}{|l|}{ Freundlich } \\
\hline $\mathrm{K}_{\mathrm{F}}(\mathrm{mg} / \mathrm{g})$ & 2.82 & 2.53 & 1.99 & 4.93 & 4.49 & 3.74 \\
\hline $\mathrm{n}$ & 1.100 & 1.080 & 1.050 & 1.050 & 1.100 & 1.050 \\
\hline $\mathrm{r}$ & 0.9666 & 0.9787 & 0.9761 & 0.9829 & 0.9969 & 0.9770 \\
\hline \multicolumn{7}{|l|}{ D-R } \\
\hline $\mathrm{Xm}(\mathrm{mg} / \mathrm{g})$ & 2.63 & 1.68 & 1.61 & 5.86 & 5.02 & 4.48 \\
\hline $\mathrm{B}\left(\mathrm{kJ}^{2} / \mathrm{mol}^{2}\right)$ & 0.0455 & 0.040 & 0.0472 & 0.0498 & 0.0415 & 0.0473 \\
\hline $\mathrm{E}(\mathrm{kJ} / \mathrm{mol})$ & 3.310 & 3.540 & 3.250 & 3.170 & 3.470 & 5.890 \\
\hline r & 0.9843 & 0.9822 & 0.9860 & 0.9932 & 0.9933 & 0.9764 \\
\hline \multicolumn{7}{|l|}{ Flory-Huggins } \\
\hline $\mathrm{n}_{\mathrm{FH}}$ & 2.090 & 2.100 & 2.680 & 1.480 & 1.620 & 1.250 \\
\hline $\mathrm{K}_{\mathrm{FH}}\left(10^{6}\right)$ & 9.050 & 7.460 & 7.760 & 6.450 & 10.17 & 2.890 \\
\hline$\Delta \mathrm{G}(\mathrm{kJ} / \mathrm{mol})$ & -39.02 & -38.55 & -38.65 & -38.19 & -40.65 & -38.72 \\
\hline $\mathrm{r}$ & 0.9440 & 0.9390 & 0.9617 & 0.9771 & 0.9775 & 0.9514 \\
\hline \multicolumn{7}{|l|}{ Halsey } \\
\hline $\mathrm{n}_{\mathrm{H}}$ & -0.476 & -0.458 & -0.456 & -1.122 & -1.176 & -1.137 \\
\hline $\mathrm{K}_{\mathrm{H}}(\mathrm{L} / \mathrm{g})$ & 1.530 & 1.440 & 1.270 & 6.042 & 6.042 & 4.810 \\
\hline $\mathrm{r}$ & 0.9739 & 0.9772 & 0.9780 & 0.9909 & 0.9959 & 0.9971 \\
\hline
\end{tabular}

\section{D-R isotherm}

In order to evaluate the nature of adsorption (chemical or physical) the data was tested by $\mathrm{D}-\mathrm{R}$ isotherm (equation 2).

$\mathrm{Lnq}_{\mathrm{e}}=\ln \mathrm{K}_{\mathrm{D}-\mathrm{R}}-\beta \varepsilon^{2}$

Where $\varepsilon$ is Polanyi potential $(\varepsilon=$ $\mathrm{RT} \ln \left(1+1 / \mathrm{C}_{\mathrm{e}}\right), \mathrm{R}$ general gas constant $(\mathrm{kJ} / \mathrm{mol}), \mathrm{K}$ adsorption capacity, $\mathrm{T}$ absolute temperature (Kelvin) and $\beta$ constant used to calculate energy $\left(\mathrm{mol}^{2} / \mathrm{kJ}^{2}\right)$.

$$
\mathrm{E}=-\frac{1}{\sqrt{2 \beta}}
$$

Fitting of the data to the equation demonstrates that filling of uniform pores of the sorbent by metal ions rather than layer by layer surface coverage of sorbate. Sorption may be attributed to the Vander Waal's forces. Energy values of sorption (Table 1) calculated for As(III) and $\mathrm{As}(\mathrm{V})$ were in range of 3.25-5.89 $(<8)$ showing the physical nature of sorption [19]. It means there was no any chemical bonding between the arsenic ions and the sorbent.

\section{Flory-Huggins isotherm}

This isotherm is used for the estimation of the degree of surface coverage on sorbent and to measure the apparent Gibbs free energy of change [20]. Flory-Huggins equation (equation 3) is given below.

$$
\begin{aligned}
& \log \frac{\theta}{\mathrm{C}_{\mathrm{i}}}=\log \mathrm{K}_{\mathrm{FH}}+\mathrm{n}_{\mathrm{FH}} \log (1-\theta) \\
& \theta=1-\frac{\mathrm{C}_{\mathrm{e}}}{\mathrm{C}_{\mathrm{i}}}
\end{aligned}
$$

Whereas $\theta$ is degree of surface coverage, $\mathrm{n}_{\mathrm{FH}}$ is the Flory-Huggins model exponent represents the number of metal ions of solute occupy active sites of sorbent, $\mathrm{K}_{\mathrm{FH}}$ is the Flory-Huggins model equilibrium constant and $\mathrm{C}_{\mathrm{e}}$ equilibrium metal ion concentration. The values of $\mathrm{K}_{\mathrm{FH}}$ and $\mathrm{n}_{\mathrm{FH}}$ were determined from slope and intercept respectively from the plot $\log \theta / C_{i}$ versus $\log (1-\theta)$. High values of correlation coefficient of $\mathrm{As}(\mathrm{III})$ and $\mathrm{As}(\mathrm{V})$ show the excellent applicability of the isotherm. Table 1 shows that as temperature increases number of metal occupying sorption sites increases for As(III) and decreases for As(V). This causes the increase sorption reaction. $\mathrm{K}_{\mathrm{FH}}$ was also used to determine the Gibbs free energy of spontaneity $\left(\Delta \mathrm{G}^{\mathrm{o}}\right)$ by following relationship.

$\Delta \mathrm{G}^{\circ}=-\mathrm{RT} \ln \mathrm{K}_{\mathrm{FH}}$

\section{Halsey isotherm}

According to this isotherm, multilayer on the surface of sorbent can be composed of three regions: non-cooperative sorption on a strongly heterogeneous surface; cooperative multilayer sorption induced by small Vander Waal's perturbation at some distance from the surface and cooperative sorption on a still heterogeneous surface. The linear form of Halsey (Halsey, 1948) adsorption isotherm (equation 4 ) is given below.

$$
\ln \mathrm{q}_{\mathrm{e}}=\frac{1}{\mathrm{n}_{\mathrm{H}}} \ln \mathrm{K}_{\mathrm{H}}-\frac{1}{\mathrm{n}_{\mathrm{H}} \ln \mathrm{C}_{\mathrm{e}}}
$$


Where $\mathrm{K}_{\mathrm{H}}$ and $\mathrm{n}_{\mathrm{H}}$ are Halsey isotherm constants. This equation is used for the multilayer adsorption [21]. Table 1 shows high value of correlation coefficient ( $r=9739)$ which attests the heteropososity (i.e. macropore and micropore) nature of the sorbent. The heteroporous nature favors the different intensities of surface sorption at various sites of the Morus alba sorbent.

\section{Kinetic study}

Kinetic study describes the pathway of reaction along time to reach equilibrium. Kinetics depends on the chemical and physical composition of sorbent.

\section{Pseudo first order rate equation}

The sorption of $\mathrm{As}(\mathrm{III})$ and $\mathrm{As}(\mathrm{V})$ onto Morus alba was analyzed by applying observed experimental data to the following linear form of Legregren equation (equation 5).

$\operatorname{Ln}\left(\mathrm{q}_{\mathrm{e}}-\mathrm{q}_{\mathrm{t}}\right)=\operatorname{lnq}_{\mathrm{e}}-\mathrm{kt}$

Where $\mathrm{k}$ is first-order rate constant (describe the transportation of metal ions from bulk aqueous solution to sorbent), $\mathrm{q}_{\mathrm{e}}$ is amount of metal sorbed at equilibrium and $\mathrm{q}_{\mathrm{t}}$ is amount of As(III) and $\mathrm{As}(\mathrm{V})$ metal ions sorbed at time $\mathrm{t}$. The rate of sorption of metal ions onto the sorbent surface is proportional to the amount of metal ions sorbed from the solution phase. $\ln \left(\mathrm{q}_{\mathrm{e}}-\mathrm{q}_{\mathrm{t}}\right)$ was plotted against $t$. The values of $\mathrm{q}_{\mathrm{e}}$ and $\mathrm{k}$ were calculated from the slope and intercept. The graph was linear up to $120 \mathrm{~min}$ (Fig. 4). This indicates that sorption is first order. Beyond 120 min data did not follow the lagergren equation.

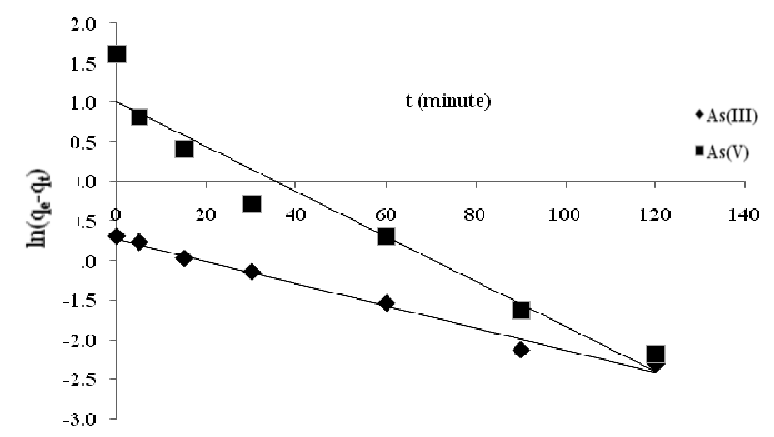

Figure 4. Pseudo-first order plot for the sorption of As(III) and As(V) on Morus alba leaves

\section{Intra particle diffusion (Morris-Weber equation)}

Intra-particle diffusion model (equation 6) is used to confirm the influence of mass transfer resistance on binding of metal ions to adsorbent.

$\mathrm{q}_{\mathrm{t}}=\mathrm{k}_{\mathrm{id} \sqrt{\mathrm{t}}}+\mathrm{C}$

Where $\mathrm{q}_{t}$ is adsorption capacity of metal on adsorbent at time $\mathrm{t}(\mathrm{mg} / \mathrm{g}), \mathrm{k}_{\mathrm{id}}$ intra-particle diffusion rate constant $\left(\mathrm{mg} / \mathrm{g} \cdot \mathrm{min}^{1 / 2}\right)$ and $\mathrm{C}$ intercept which gives idea of thickness of boundary layer. The graph was plotted $\mathrm{q}_{\mathrm{t}}$ versus $\mathrm{t}^{1 / 2}$. According to Fig. 5 and Table 2, As(III) and As $(\mathrm{V})$ experimental data follow equation up to 360 minutes with $\mathrm{k}_{\mathrm{id}}$ values $1.34 \mathrm{mg} / \mathrm{g} \mathrm{min}^{1 / 2}$ and $1.01 \mathrm{mg} / \mathrm{g} \mathrm{min}^{1 / 2}$ respectively and then deviated. Linear portion of the plot is not passing through origin indicated that the intra-particle diffusion was not only the rate limiting step [22]. It supports that sorption mechanism is complex; Intra-particle diffusion as well as surface sorption occurs. Same trend was also observed for adsorption of As on bone char.

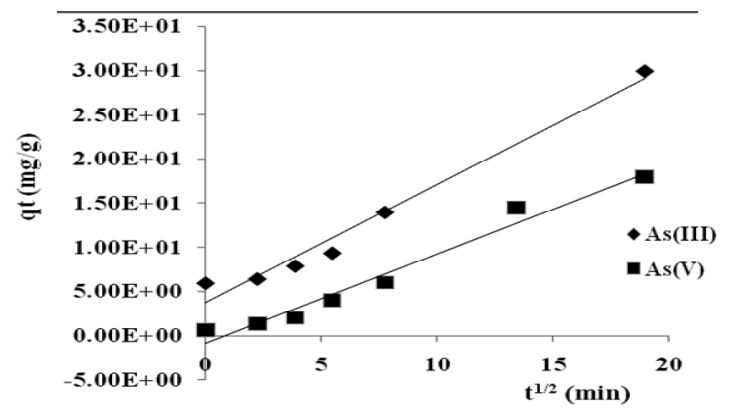

Figure 5. Morris-Weber plot for the sorption of $\mathrm{As}(\mathrm{III})$ and $\mathrm{As}(\mathrm{V})$ on Morus alba leaves

Table 2. Kinetics parameters for the sorption of $\mathrm{As}(\mathrm{III})$ and $\mathrm{As}(\mathrm{V})$ on Morus alba leaves at various temperatures.

\begin{tabular}{|c|c|c|c|c|c|c|}
\hline \multirow[t]{2}{*}{ Metals } & \multicolumn{4}{|c|}{ First order rate equation } & \multicolumn{2}{|c|}{$\begin{array}{c}\text { Intra-particle } \\
\text { Diffusion }\end{array}$} \\
\hline & $\begin{array}{c}\mathbf{k} \\
\left(\mathrm{min}^{-1}\right)\end{array}$ & $\begin{array}{c}\mathbf{q}_{\mathrm{e}} \\
(\mathrm{mg} / \mathrm{g})\end{array}$ & $\begin{array}{c}\text { h } \\
(\mathrm{mg} / \mathrm{g} . \\
\mathrm{min}) \\
\end{array}$ & $\mathbf{r}$ & $\begin{array}{c}\mathbf{k}_{\mathrm{id}} \\
(\mathrm{mg} / \mathrm{g} . \\
\left.\min ^{1 / 2}\right)\end{array}$ & $\mathbf{r}$ \\
\hline$\overline{\mathrm{As}(\mathrm{III})}$ & 0.014 & 0.48 & 0.003 & 0.9931 & 1.34 & 0.9884 \\
\hline $\operatorname{As}(V)$ & 0.028 & 2.77 & 0.220 & 0.9697 & 1.01 & 0.9861 \\
\hline
\end{tabular}

\section{Richenberg equation}

The mechanism of sorption of arsenic ions on Morus alba through film diffusion or intra particle diffusion was described by Richenberg model (equation 7). 
$\mathrm{Q}=\frac{1-6 \pi^{-\mathrm{Bt}}}{\pi^{2}}$

Where $\mathrm{Q}=\mathrm{qt} / \mathrm{qm}, \mathrm{Bt}=\pi^{2} \mathrm{Di} / \gamma^{2}$, qt is sorption capacity of metal at time $\mathrm{t}$, $\mathrm{qm}$ is maximum sorption capacity of the sorbent, Di is an effective diffusion co-efficient of ions exchanging inside the sorbent particle. The value of Bt can be calculated for the each value of $\mathrm{Q}$ using following equation 8 .

$\mathrm{Bt}=-0.4977-\ln (1-\mathrm{Q})$

The plots of $\mathrm{Bt}$ versus $\mathrm{t}$ of $\mathrm{As}$ (III) and $\mathrm{As}(\mathrm{V})$ are linear from 0 to 60 minutes with a regression coefficient of 0.9922 and 0.9931 . Fig. 6 shows that regression lines of plot of As(III) and As(V) are not passing through origin it means that the thin metal film is formed on the surface of Morus alba sorbent [23].

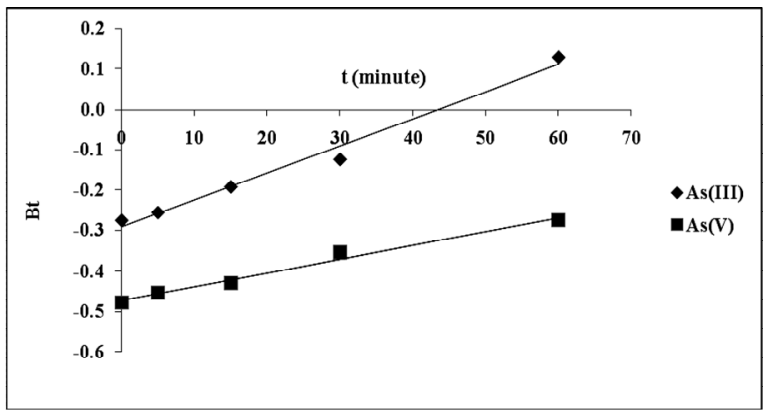

Figure 6. Richenberg plot for the sorption of $\mathrm{As}(\mathrm{III})$ and $\mathrm{As}(\mathrm{V})$ on Morus alba leaves

\section{Thermodynamic study}

Thermodynamic study helps in estimating the possibility and nature of adsorption process. Thermodynamic parameter Gibbs free energy was calculated by using the following equation 9 [24].

$\Delta \mathrm{G}=-\mathrm{RT} \ln \mathrm{K}_{\mathrm{C}}$

Where $\Delta \mathrm{G}$ is Gibbs free energy, $\mathrm{R}$ general gas constant $(8.3143 \mathrm{~J} / \mathrm{mol} . \mathrm{K}), \quad \mathrm{K}_{\mathrm{c}}$ is equilibrium constant and $\mathrm{T}$ solution temperature $(\mathrm{K}) . \mathrm{K}_{\mathrm{c}}$ is determined by following equation 10 .

$\mathrm{K}_{\mathrm{C}}=\frac{\mathrm{C}_{\mathrm{a}}}{\mathrm{C}_{\mathrm{e}}}$

Where $C_{a}$ is equilibrium concentration of the As ions sorbed on mulberry $(\mathrm{mg} / \mathrm{L})$ and $\mathrm{C}_{\mathrm{e}}$ is equilibrium concentration of arsenic ions in solution $(\mathrm{mg} / \mathrm{L})$.
Enthalpy change $(\Delta \mathrm{H})$ and entropy change $(\Delta \mathrm{S})$ were calculated by plotting $\ln \mathrm{K}_{\mathrm{c}}$ versus $1 / \mathrm{T}$. Table 1 (Flory-Huggins Isotherm) and Table 3 show that Gibbs free energy values of both As(III) and $\mathrm{As}(\mathrm{V})$ are negative means the sorption reaction of As ions on Morus alba leave was feasible and spontaneous (i.e adsorption forces are strong to overcome potential barrier). Decrease of negative value with the increase of temperature shows that an increase of the temperature does not favor sorption process. Result shows that the sorption of $\mathrm{As}(\mathrm{V})$ was more feasible than As(III). Other two thermodynamic parameters (entropy change and enthalpy change) were calculated by using following equation 11 [25].

$\ln \mathrm{K}_{\mathrm{C}}=\frac{\Delta \mathrm{S}}{\mathrm{R}}-\frac{\Delta \mathrm{H}}{\mathrm{RT}}$

The values of $\Delta \mathrm{H}$ and $\Delta \mathrm{S}$ were determined from slope and intercept from the plot $\operatorname{lnK}_{\mathrm{c}}$ versus $1 / \mathrm{T}$. In Table 3 negative values of $\Delta \mathrm{S}$ for $\mathrm{As}(\mathrm{III})$ and $\mathrm{As}(\mathrm{V})$ show that there was orderliness (immobilization or fixation) of sorbate ions on surface of sorbent during the process. Positive values of enthalpy change $(\Delta \mathrm{H})$ for both species of As indicates that sorption process is an endothermic.

Table 3. Thermodynamic constants for the sorption of As(III) and $\operatorname{As}(\mathrm{V})$ on the Morus alba leaves at different temperatures.

\begin{tabular}{lcccc}
\hline Metals & $\begin{array}{c}\text { Temp. } \\
(\mathbf{K})\end{array}$ & $\begin{array}{c}\Delta \mathbf{G} \\
(\mathbf{K J} / \mathbf{m o l})\end{array}$ & $\begin{array}{c}\Delta \mathbf{H} \\
(\mathbf{K J} / \mathbf{m o l})\end{array}$ & $\begin{array}{c}\Delta \mathbf{S} \\
(\mathbf{J ~ m o l} / \mathbf{K})\end{array}$ \\
\hline As(III) & 293 & -5.87 & & \\
& 303 & -5.47 & 17.91 & -0.041 \\
& 313 & -5.05 & & \\
As(V) & 293 & -6.68 & & \\
& 303 & -5.64 & 29.41 & -0.078 \\
& 313 & -5.13 & & \\
\hline
\end{tabular}

\section{Desorption/ regeneration study}

To make sorption method more economical, therefore, it is necessary to desorb the metals and metalloids sorbed. Desorption process yields metal ions in concerted form, facilitate their disposal and restore sorbent for effective reuse [26]. $0.1 \mathrm{~g}$ of As (10 mg/L) loaded biomass was added to $5 \mathrm{~mL}$ of leaching agent (desorbent) in a stoppered conical flask. Various leaching agents (acids and bases of varying concentrations) were used. The contents of flask were agitated at 250 
rpm for 30 min maintaining the temperature at 25 ${ }^{\circ} \mathrm{C}$. The mixture was filtered by filter paper. After the washing of Morus alba sorbent, filtrate was analyzed by atomic absorption spectrometer connected with FIA system. Maximum 83.3\% and 95.52\% recoveries of $\mathrm{As}(\mathrm{III})$ and $\mathrm{As}(\mathrm{V})$, respectively were obtained with $1 \mathrm{M} \mathrm{H}_{2} \mathrm{SO}_{4}$.

\section{Interference study}

Before applying the developed method in real samples, it is important to investigate the effect of electrolytes on the removal efficiency of Morus alba leave sorbent because real samples contain various electrolytes. Effect of some common electrolytes in the ratios of 1:10 and 1:100 were examined on the removal efficiency of As(III) and As(V) by Morus alba leaves. In 1:10 ratio $7.5 \mathrm{~mL}$ of $\mathrm{As}(10 \mathrm{mg} / \mathrm{L})$ and $0.075 \mathrm{~mL}$ of an electrolyte $(10000 \mathrm{mg} / \mathrm{L})$ were taken in $15 \mathrm{~mL}$ volumetric flask. In case of 1:100 ratio $7.5 \mathrm{~mL}$ of As $(10 \mathrm{mg} / \mathrm{L})$ and $0.75 \mathrm{~mL}$ of an electrolyte $(10000 \mathrm{mg} / \mathrm{L})$ were taken in $15 \mathrm{~mL}$ volumetric flask. After maintaining optimum $\mathrm{pH}$, volumes of both flasks were made up to $20 \mathrm{~mL}$. According to histogram Fig. 7 and Fig. 8 As(III) and As(V), respectively with Iron(III) show maximum removal of As ions.

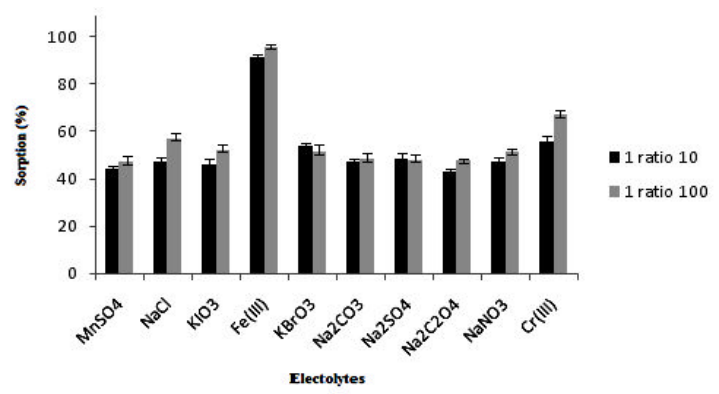

Figure 7. Electrolytic effect on the sorption of As(III) ions on Morus alba leaves

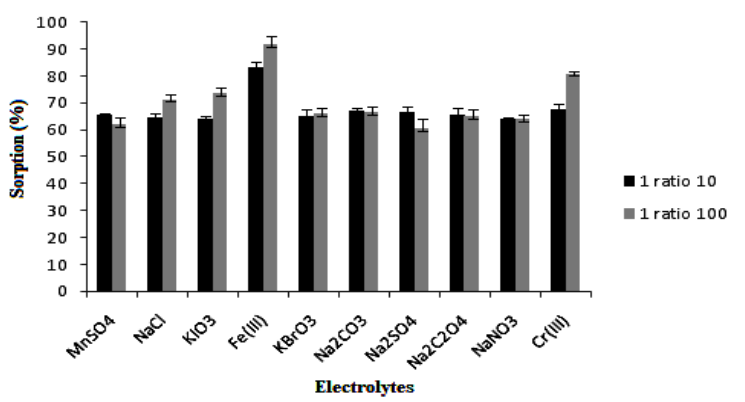

Figure 8. Electrolytic effect on the sorption of $\mathrm{As}(\mathrm{V})$ ions on Morus alba leaves

\section{Applications}

The developed method was applied to remove the As metal ions from the contaminated water samples. Sample (S1) Industrial effluents of Kotri Site area, District Jamshoro, Pakistan was collected from the draining point in Karachi Wah. The sample (S2) tube well water near United Etanol Industry Sadiqabad, District Rahimyar Khan, Pakistan. Up to $89.84 \%$ of As was successfully removed from the As contaminated water samples (Table 4).

Table 4. Removal of Arsenic from real water samples.

\begin{tabular}{ccccc}
\hline Sample & $\begin{array}{c}\text { Original } \\
\text { Arsenic } \\
\text { Concentration } \\
\text { in Sample } \\
\left(\boldsymbol{\mu g L} \mathbf{L}^{-1}\right)\end{array}$ & $\begin{array}{c}\text { Amount of } \\
\text { Arsenic } \\
\text { Added } \\
\left(\boldsymbol{\mu g L} \mathbf{L}^{-1}\right)\end{array}$ & $\begin{array}{c}\text { Recovery } \\
(\%)\end{array}$ & $\begin{array}{c}\text { Residual } \\
\text { Concentration } \\
\left(\boldsymbol{\mu g L} \mathbf{L}^{-1}\right)\end{array}$ \\
\hline 1 & 40 & --- & 75.28 & 9.89 \\
& 40 & 50 & 89.84 & 9.14 \\
2 & 0.68 & 50 & 74.13 & 10.14 \\
\hline
\end{tabular}

Table 5. Comparative capacities of different sorbents and Morus alba.

\begin{tabular}{|c|c|c|c|c|c|c|}
\hline \multirow[b]{2}{*}{ Adsorbents } & \multirow[b]{2}{*}{ Metals } & \multicolumn{3}{|c|}{$\begin{array}{l}\text { Optimized } \\
\text { conditions }\end{array}$} & \multirow[t]{2}{*}{$\begin{array}{l}\text { Capacity } \\
\left(\mathrm{mg}^{-1} \mathrm{~g}^{-1}\right)\end{array}$} & \multirow[b]{2}{*}{ Reference } \\
\hline & & $\mathbf{p H}$ & $\begin{array}{l}\text { Time } \\
(\min )\end{array}$ & $\begin{array}{c}\text { Temp } \\
\left({ }^{\circ} \mathrm{C}\right)\end{array}$ & & \\
\hline \multirow{2}{*}{$\begin{array}{l}\text { Aspergillus } \\
\text { niger biomass }\end{array}$} & As (III) & 6 & 420 & 30 & 0.086 & [10] \\
\hline & As (V) & 6 & 420 & 30 & 0.1 & \\
\hline $\begin{array}{l}\text { Grape fruit peel } \\
\text { waste }\end{array}$ & As (V) & 4 & 120 & 45 & 37.76 & [12] \\
\hline Cod fish scale & As (III) & 4 & - & - & 0.025 & [15] \\
\hline \multirow{3}{*}{$\begin{array}{l}\text { Lamarck seed } \\
\text { powder }\end{array}$} & As (V) & 4 & - & - & 0.027 & \\
\hline & As (III) & 7.5 & 60 & - & 1.5 & [27] \\
\hline & As (V) & 2.5 & 60 & - & 2.16 & \\
\hline Hematite & As (V) & 4.2 & - & 30 & 0.2 & [28] \\
\hline Feldspar & As (V) & 4.2 & & 30 & 0.18 & \\
\hline $\begin{array}{l}\text { Bauxol } \\
\text { (Neutralized } \\
\text { red mud) }\end{array}$ & As (V) & 4.5 & - & 23 & 1.081 & [29] \\
\hline $\begin{array}{l}\text { Dry water } \\
\text { hyacinth plant } \\
\text { leaf }\end{array}$ & As (V) & & - & - & 0.34 & {$[30]$} \\
\hline Oliver soil & $\operatorname{As}(\mathrm{V})$ & $5-6$ & - & 25 & 0.42 & [31] \\
\hline Sharkey soil & As (V) & $5-6$ & - & 25 & 0.74 & \\
\hline Winder soil & As $(\mathrm{V})$ & $5-6$ & - & 25 & 0.55 & \\
\hline $\begin{array}{l}\text { Orange peel } \\
\text { waste }\end{array}$ & As (V) & 7 & 120 & 45 & 132 & [32] \\
\hline \multirow[t]{2}{*}{ Morus alba } & As (III) & 6 & 120 & 20 & 2.82 & This study \\
\hline & $\mathrm{AS}(\mathrm{V})$ & 4 & 120 & 20 & 4.93 & \\
\hline
\end{tabular}




\section{Conclusion}

The proposed method demonstrate that Morus alba leaves has great potential as a sorbent for the removal of $\mathrm{As}(\mathrm{III})$ and $\mathrm{As}(\mathrm{V})$ simultaneously. The results reveal that Morus alba leaves has better As removal efficiency as compared to many sorbents as mentioned in Table 5. At $\mathrm{pH}-6$ and $\mathrm{pH}-4, \mathrm{As}(\mathrm{III})$ and $\mathrm{As}(\mathrm{V})$, respectively showed maximum sorption capacity $2.82 \mathrm{mg} / \mathrm{g}$ and $4.93 \mathrm{mg} / \mathrm{g}$ on Morus alba leaves sorbent. Kinetically, experimental data follow the Pseudo first order rate equation. Furthermore, thermodynamic parameters Gibbs free energy and enthalpy change values indicate the sorption reaction is spontaneous and endothermic in nature. The proposed method was applied on contaminated water samples which show that up to $89.84 \%$ of As was successfully removed.

\section{References}

1. M. E. Pena, G. P. Korfiatis, M. Patel, L. Lippincott and X. Meng, Water Res., 39 (2005) 2327.

doi.10.1016/waters.2005.04.006.

2. L. Lorenzen, J. S. J. Van Deventer and W. M. Landi, Miner. Eng., 8, (1995) 557. doi.10.1016/0892-6875(95)00017-K.

3. P. S Keng, S. L. Lee, S. T. Ha, Y. T. Hung and S. T. Ong, Environ. Chem. Lett., 12 (2014) 15.

doi.org/10.1007/s10311-013-0427-1.

4. P. K. Pandey, S. Choubey, Y. Verma, M. Pandey and K. Chandrashekhar, Bioresour. Technol., 100 (2009) 634. doi.10.1016/j.biortech.2008.07.063

5. B. K. Mandal and K. T. Suzuki, Talanta, 58 (2002) 201. doi.org/10.1016/S0039-9140(02)00268-0

6. Z. Li, S. Mou, Z. Ni and J. M. Riviello, Anal. Chim. Acta, 307 (1995) 79. doi.org/10.1016/0003-2670(95)00030-4

7. D. Mohan, C. U. Pittman, M. Bricka, F. Smith, B. Yancey, J. Mohammad, P. H. Steele, PA. H. lexandre-Franco, V. G. Serrano and H. Gong and H. J. Colloid, Interf. Sci., 310 (2007) 57. doi.10.1016/j.icis.2007.01.020

8. M. Aryal, M. Ziagova and M. LiakopoulouKyriakides, Chem. Eng. J., 162 (2010) 178. doi.10.1016/j.cej.2010.05.026

9. N. E. Korte and Q. Fernando, Crit. Rev. Environ. Control, 21 (1991) 1. doi.org/10.1080/10643389109388408

10. D. Pokhrel and T. Viraraghavan, J. Hazard. Mater., 150 (2008) 818.

doi.10.1016/i.jhazmat.2007.05.041

11. M. Tuzen, A. Sari, D. Mendil, O. D. Uluozlu, D. Soylak and M. Dogan, J. Hazard. Mater., 165 (2009) 566.

doi.10.1016/j.jhazmat.2008.10.020

12. W. Zhan, C. Xu, G. Qian, G. Huang, X. Tang and B. Lin, RSC Adv., 8 (2018) 18723. doi: 10.1039/C8RA02055H

13. A. Kuroki, M. Hiroto, Y. Urushihara, T. Horikawa, K. I. Sotowa and J. R. A. Avila, Adsorption, 25 (2019) 1251.

https://doi.org/10.1007/s10450-019-00069-7

14. A. Sari and M. Tuzen, J. Hazard. Mater., 164 (2009) 1372.

doi.10.1016/j.jhazmat.2008.09.047

15. B. K. Biswas, I. Jun-ichi, K. Inoue, N. Ghimire, H. Harada, K. Ohto and $\mathrm{H}$. Kawakita, J. Hazard. Mater., 154 (2008) 1066. doi.1016/j.jhazmat.2007.11.030

16. T. Sua, B. X. Guanc, Y. B. Tanga, G. Gub, and J. Wanga, J. Hazard. Mater., 176 (2010) 466. doi.1016/j.jhazmat.2009.11.052

17. J. Febrianto, A. N. Kosasih, J. Sunarso, Y. H. Ju, N. Indraswati and S. Ismadji, $J$. Hazard. Mater., 162 (2009) 616. doi.org/10.1016/j.jhazmat.2008.06.042

18. G. Onaran, L. Gurel and H. Argun, Int. J. Enviro. Sci. Technolo., 17 (2020) 799. https://doi.org/10.1007/s13762-019-02499$\underline{w}$

19. N. Ayawei, A. Newton Ebelegi and D. Wankasi, J. Chem., (2017) 1. https://doi.org/10.1155/2017/3039817

20. M. R. Samarghandi, M. Hadi, S. Moayedi and F. B. Askari, Iranian J. Environ. Health Sci. Eng., 6 (2009) 285.

https://www.sid.ir/en/Journal/ViewPaper.asp $\mathrm{x}$ ?ID $=163992$

21. A. O. Nurudeen, O. A. Issac, A. I. Justice and E. E. Emmanuel, Central Eur. J. Chem., 7 (2009) 760. doi.10.2478/s11532-009-0098--8 
22. Y. N. Chen, L. Y. Chai and Y. D. Shu, J. Hazard. Mater., 160 (2008) 168.

doi.10.1016/j.jhazmat.2008-02-120

23. M. I. Khaskheli, S. Q. Memon, W. B. Jatoi, Z. A. Chandio, G. K Shar, A. Malik and S. Khan, Global Nest J., 19 (2017) 278. https://doi.org/10.30955/gnj.001944

24. V. Sarin, T. S. Singh and K. K. Pant, Bioresour. Technol., 97 (2006) 1986. doi.10.1016/j.biortech.2005.10.001

25. A. C. Q. Ladeira and V. S. T. Ciminelli, Water Res., 38 (2004) 2087. doi.10.1016/j.waters.2004-02-002

26. P. Kumari, P. Sharma, S. Srivastava and M. M. Srivastava, Int. J. Mine. Process., 78 (2006) 131. doi.10.1016/j.minpro.2005.10.001

27. D. Ranjan M. Talat and S. H. Hasan, $J$. Hazard. Mater., 166 (2009) 1050. doi.10.1016/j.jhazmat.2008.12.013
28. H. Genc-Fuhrman, J. C. Tjell and D. McConchie, Environ. Sci. Technol., 38 (2004) 2428.

doi.10.1021/es0355207h

29. F. E. Chigbo, R. W. Smith and F. L. Shore, Environ. Pollut. Series A Ecol. Biol., 27 (1982) 31.

doi.10.1016/0143-1471(82)90060-5

30. S. Maity, S. Chakravarty, S. Bhattacharjee and B. C. Roy, Water Res., 39 (2005) 2579. doi.10.1016/j.waters.2005-04-054

31. H. Zhang and H. M. Selim, Environ. Sci. Technol., 39 (2005) 6101. doi.10.1021/es050334u

32. M. I. Khaskheli, S. Q. Memon, A. N Siyal and M. Y. Khuhawar, Waste Biomass Valor., 2 (2011) 423.

doi.10.1007/s12649-011-9081-7 